\title{
Health Promotion Model for Adolescent Reproductive Health
}

\author{
Tri Sunarsih ${ }^{1 *}$, Endah Puji Astuti ${ }^{1}$, Elvika Fit Ari Shanti ${ }^{1}$, Eny Retna Ambarwati ${ }^{2}$
}

\begin{abstract}
${ }^{1}$ Universitas Jenderal Achmad Yani, Yogyakarta, INDONESIA
${ }^{2}$ Sekolah Tinggi Ilmu Kesehatan AKBIDYO, INDONESIA

*Corresponding Author: are_she79@yahoo.com
\end{abstract}

Citation: Sunarsih T, Astuti EP, Ari Shanti EF, Ambarwati ER. Health Promotion Model for Adolescent Reproductive Health. Electron J Gen Med. 2020;17(3):em212. https://doi.org/10.29333/ejgm/7873

\section{ARTICLE INFO}

Received: 23 Nov. 2019

Accepted: 26 Feb. 2020

\begin{abstract}
This study aims to assess the factors that influence adolescent reproductive health. Many factors affect adolescent reproductive health issues including Knowledge, access to reproductive health information sources, stakeholder support, health promotion of reproductive health, and role of parents. The method used in this research is explorative quantitative. Data was collected using a survey method with a cross-sectional approach. The respondent is a grade VII student of SMP Muhammadiyah 1 Mlati, Sleman, Yogyakarta. Data analysis uses Structural Equation Modelling (SEM). The final results of the study show that the model of promoting good health about adolescent reproductive health is designed by improving the process of promoting health about reproductive health for adolescents themselves, stakeholders, and parents. Increase access to information, the role of stakeholders and the role of parents.
\end{abstract}

Keywords: health promotion, adolescent, reproductive health

\section{INTRODUCTION}

Teenagers are the hope of the nation, healthy and quality teenagers are a serious concern for parents, for education practitioners, as well as for adolescents themselves. The problem of adolescents with their reproductive organs received less attention because of their relatively young age, still in educational status and as if adolescents were free from the possibility of facing complications and diseases related to their reproductive organs. Lately, a lot of sexual violence has taken place. Commonly, many teenage boys stated that they had had pre-marital sex compared to women. This reflects the lack of understanding of adolescents about healthy living skills, the risk of sexual relations and the ability to reject relationships that they do not want.

Similarly, the symptoms of PMS are less known by teenagers. Information on HIV is relatively more widely accepted by adolescents, although only $9.9 \%$ of adolescent girls and $10.6 \%$ of men have comprehensive knowledge about HIV-AIDS. Adolescent service places are also not widely known by teenagers (1). Reproductive Health Education can be given from an early age by parents and education personnel at school. It is hoped that the school will provide learning about ethics and morals in everyday life more than state schools. So, students will be more polite and behave better. In accordance with religious rules understood it is prohibited, but still do. Students also do not know about reproductive health and have never accessed reproductive health information through media such as online media that are easily found. Students only utilize board media such as wall magazines provided in schools and guidance by Guidance Counseling (BK) teachers.
Interview with one of the teachers said that students did not know much about reproductive health. Students only know about reproductive health about menstruation, make friends with the opposite sex, and do not know broadly about other reproductive health.

The unavailability of accurate information about reproductive health forces young people to seek access and explore on their own. This is then the teenagers look for information that is not necessarily true of its accuracy and truth, which in the end can actually plunge adolescents into reproductive unhealthiest. reproductive health problems that often occur namely menstruation, anxiety when first menstruation comes, dysmenorrhea, vaginal discharge, dating, free promiscuity, and self-confidence when experiencing changes in their bodies, especially in changes in the reproductive organs. While in students the problems that often occur are fighting, anxiety when having wet dreams, dating, smoking, and promiscuity. In connection with holding a health promotion process in health promotion is very important to facilitate the implementation of health promotion.

The Indonesian government's efforts to reduce maternal and infant mortality rates are with a healthy Indonesia program that focuses on the movement of healthy living communities, a family approach, and minimum service standards. Based on Presidential Regulation no.2 of 2018 regarding minimum service standards in the health sector, one of the standards contained is that every Indonesian citizen aged 15-59 years receives health screening according to the standard (1). The World Health Organization (WHO) defines youth as a group of people aged between 15 and 24 years characterized by the rapid development of sexual 
characteristics secondary to sexual and reproductive maturation. This period is a period of many challenges. One of the challenges is the initiation of early sex makes many young people experience sexual and reproductive health problems. Identification of factors related to adolescent reproductive health is very important to develop effective policies and strategies to reduce sexual premature. Therefore, this study aims to assess the factors that influence adolescent reproductive health in SMK Muhammadiyah 1 Mlati Sleman Yogyakarta.

\section{LITERATURE REVIEW}

Several epidemiological studies show that early sexual intercourse is associated with low levels of contraceptive use, and drug use during intercourse (2). This behavior impacts on unplanned pregnancy and sexually transmitted infections at the time of its development. Many factors affect reproductive health, including socio-demographic, economic, behavioral, and parental characteristics (3), gender (4), place of residence (5), parental monitoring (6), adolescent's own behavioural factors, and peers (5). Other studies show that factors affecting knowledge about reproductive health include age, sources of information about preconception care services, employment, educational status, intention to conceive (7). Behavior among adolescents has been shown to be largely determined by how much their peers can accept (8). Starting from the previous literature study, this research will remind others about knowledge about reproductive health, access to reproductive health information sources, stakeholder support on reproductive health, health promotion about reproductive health, the role of parents in reproductive health education and reproductive health behaviors that can be used as a policymaker related to health promotion regarding adolescent reproductive health (9).

Negative behavior, attitudes of health care workers, poor knowledge and skills of $\mathrm{RH}$ services are associated with inadequate provision of $\mathrm{RH}$ services. In addition, the limited knowledge and competence of health workers in reproductive health services for adolescents can hinder access and utilization of services (10). Staff health and transportation costs as other barriers faced by adolescents (11). In addition, the contradictory nature of reproductive and sexual health policies and the legal age to have sex also affects adolescent behavior towards reproductive health (11).

Several studies have shown that adolescents with good knowledge about reproductive health will benefit from the available reproductive health services (12). Students with high knowledge about reproductive health and reproductive health services that are available are twice as likely to utilize adolescent reproductive health services as compared to adolescents who have low levels of knowledge (13). Information or delivery of this information can be a form of intervention on the understanding of adolescents about the importance of achieving healthy reproductive health (14). Negative health behaviors and attitudes of health workers are unlikely to encourage adolescents to access and utilize reproductive health services (15). Conversely, youth-friendly clinics with adolescent-friendly nurses are likely to encourage teenage girls to access sexual and reproductive health services and can increase their use (16). the perspective of studies on reproductive health education in parents is based exclusively on social learning approaches (17). family support needs to be improved by providing socialization programs for teenage parents so as to encourage parents and adolescents to be more open to discuss reproductive health issues (18). The role of parents does not directly affect reproductive health behavior. Basically, the fundamentals of reproductive health education are arranged from childhood and through family contributions (19). The results of this study are consistent with findings from a systematic study of studies conducted in Indonesia (20). Parent and child communication about reproductive health tends to be general and is often marked by warnings/prohibitions, not direct and open discussion. In contrast to studies in adolescents in Ethiopia that adolescents who have sex as a normal part of their lives and they are open to discuss it with parents, especially to their mothers (21). However, discussing reproductive health in Indonesia is taboo. That could be the reason that Ethiopian teenagers have higher knowledge about reproductive health and reproductive health services available than Indonesian teenagers.

This is because a large number of students begin sexual activity at an early age (22). This is consistent with the results of research that school teachers, health services, parents, other family members, and peers influence reproductive health (23). Parents feel that it is the responsibility to provide reproductive health education, especially with teachers. This may be because reproductive health education is still considered taboo (24), which negative impact on reproductive health communication between parents and adolescents. Empowering parents and teachers to provide reproductive health information to adolescents, can have a positive impact on adolescent health (25).

Research related to reproductive health has been studied since 1973. Research on information technology for health today is increasing both in terms of quantity and quality. From the literature review conducted, the model of health promotion through determinant studies that have an effect on reproductive health is not much. Related to the renewal of this research is seeing the determinants that affect reproductive health that can be used to form a model of health promotion in accordance with the conditions of the study.

\section{RESEARCH METHOD}

This type of research is a quantitative explanatory type. The study was conducted using a survey method with a crosssectional approach. This research was conducted at Muhammadiyah 1 Middle School Mlati, Sleman, Yogyakarta which involved 117 students. Data retrieved using the Cluster Sampling technique. Data analysis using Structural Equation Modeling (SEM) previously tested with parametric assumptions that can produce the best linear unbiased estimator (BLUE).

\section{RESULTS AND DISCUSSION}

\section{Determinants of Adolescent Reproductive Health Behaviors}

Model estimation in this study uses Maximum Likelihood Estimation (MLE) Based on the analysis results, the value of c.r multivariate (critical ratio) t meets the requirements of -2.58 


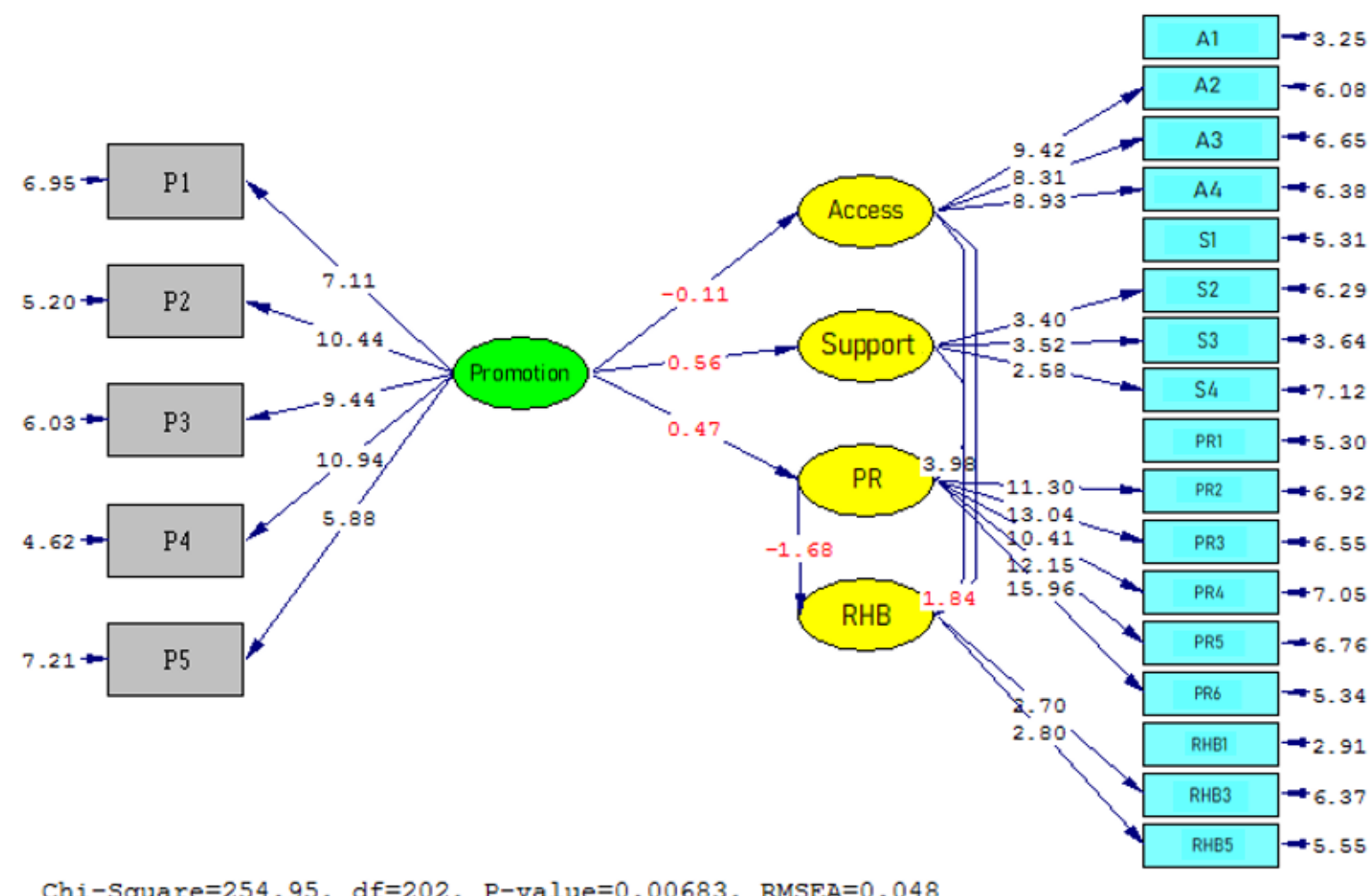

Figure 1. Determinants of Adolescent Reproductive Health Behaviors (RHB)

Table 1. Matching the modification model 2

\begin{tabular}{cccc}
\hline Indicator & Value & Cut Point & Keputusan \\
\hline Chi-Square & 254.95 & p-value $>0.05$ & Model fit \\
\hline p-value & 0.00128 & p-value $>0.05$ & Model fit \\
\hline RMSEA & 0.048 & RMSEA $<0.06$ & Model fit \\
\hline NFI & 0.85 & NFI $>0.90$ & Marginal fit \\
\hline CFI & 0.96 & CFI $>0.95$ & Model fit \\
\hline GFI & 0.83 & GFI $>0.9$ & Marginal fit \\
\hline
\end{tabular}

$<c . r<2.58$ which is equal to 5.038 . So, the data in this study are normal multivariate. Outlier test states that there is data declared outlier because it has a d-squared Mahala Nobis value of more than $(X 2,0.001,21)=46.79704$, namely on observation number 94 . So that the deletion of the outlier data at that number is done. From the output of the calculation results of the sample covariance determinant matrix, it is known that the determinant value of the sample covariance matrix is greater than 0,000 , which is the determinant of the sample covariance matrix $=28570349344491.100$. Thus, it can be concluded that there is no multicollinearity and singularity in the data of this study. The relationship between the determinants of adolescent reproductive health behavior can be seen in Figure 3 and the results of the two model relationships can be seen in Table 1.

\section{Relationship between P and RHB Variables}

The following are values for each indicator and the relationship between the $\mathrm{P}$ and $\mathrm{RHB}$ variables. It can be seen in the following diagram that only one $P$ indicator is insignificant, namely the $\mathrm{P} 1$ indicator $(t<1.96)$. RHB indicators do not show significant value. The relationship between the $P$ and $R H B$ variables is also insignificant. This indicates that the $P$ variable does not affect RHB. The relationship between health promotion and reproductive health behavior can be seen in Figure 2.
Overall the model can be said to be good. In the initial model, there are insignificant indicators and one indicator whose value is negative. While the modification model 1 and modification model two there are no indicators that are not significant. Besides that, the value of RMSEA decreases after modification to stage two. This indicates that the modification model is better than the initial model. Likewise, the values of $\mathrm{CFI}, \mathrm{GFI}$, and NFI show increasing values with each modification. This also indicates that the modification model is better than the initial model. The selection of the best model cones on modification model 1 and modification model 2 by including modification 3. Both modification models are equally good. Model modification 1 does not include RHB and RHB indicators. While modification model 2 does not include RHB and RHB indicators and adds direction to the relationship between the latent variable of access and the role of parents. Based on the results of path analysis it is found that health promotion influences stakeholder support and parental roles. health promotion does not affect access to information for adolescents, but directly influences reproductive health behavior. The results of the relationship modification model can be seen in Table 2.

Counseling of reproductive health in adolescents is very important in helping adolescents to gain knowledge, awareness, attitudes, and behavior in a healthy and responsible life. Knowledge is one of the factors driving behavior change. Adolescent knowledge about healthy behavior can influence how to behave and make decisions in their reproductive health life. Counseling is not limited to changing adolescent behavior, but to increase interaction between stakeholders so that they are able to optimize their accessibility with information so that they are able to improve adolescent reproductive health. Reproductive health education programs have been able to increase knowledge and behavior about reproductive health. 


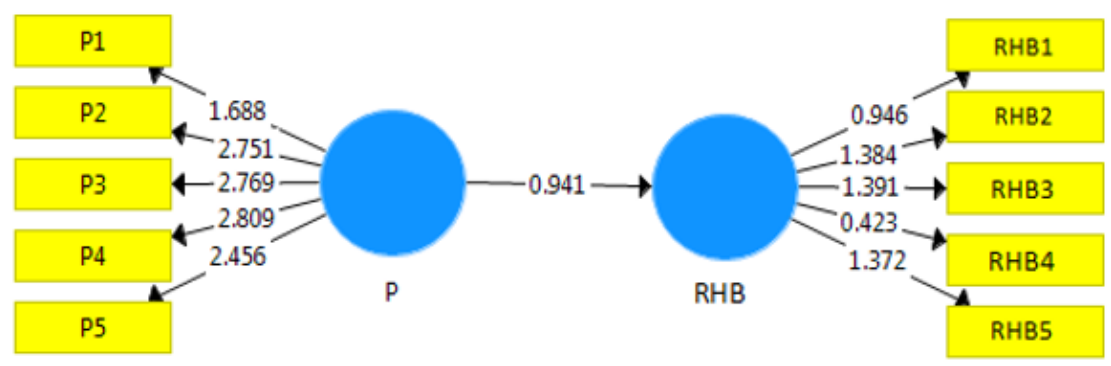

Figure 2. Relationship of Health Promotion (P) with Reproductive Health Behavior (RHB)

Table 2. Relationship Modification Model

\begin{tabular}{cccc}
\hline Criteria & First Model & Modification 1 & modification 2 \\
\hline p-value & 0.00006 & 0.00128 & 0.00683 \\
\hline RMSEA & 0.058 & 0.053 & 0.048 \\
\hline CFI & 0.93 & 0.95 & 0.96 \\
\hline GFI & 0.8 & 0.83 & 0.83 \\
\hline NFI & 0.81 & 0.84 & 0.85 \\
\hline
\end{tabular}

This study shows a positive relationship between health promotion and some reproductive health behaviors. Reproductive health education is provided in order to explain the development of skills and knowledge needed to influence adolescent decision making about healthy reproductive health. Another possible explanation is that schools use a more effective curriculum (26). Reproductive health behavior is directly affected by health promotion, access to information, stakeholder support. The role of parents does not directly affect reproductive health behavior, but must be supported by health promotion to parents. This is in line with the lack of evidence about the effectiveness of parental or familycentered interventions and programs regarding reproductive health to prevent unwanted or bad sexual behavior in children.

Family support can influence student knowledge about adolescent reproductive health and the services available because the family is one of the main sources of reproductive health information. The existence of such family support has a positive impact on the knowledge and utilization of adolescent reproductive health services. Another aspect that must be considered when developing educational programs for parents is the dimension that contributes to the effectiveness of parenting programs in schools in general.

In this study, it was found that parents had limited knowledge about reproductive health and rarely discussed it with their children. Most parents in research give warnings to maintain virginity and avoid pregnancy. The results of the study highlight the need to improve parenting skills through the construction of interventions directed at parent-teen communication around reproductive health. Such interventions can form the foundation to strengthen health programs for adolescents (27). Further research needs to be considered that the possibility of communication is associated with adolescence, parental education, and parental type. From the results of the study, it can be understood that this is an urgent need to provide an understanding of parents who have at least basic knowledge and reproductive health skills in order to be able to provide knowledge to their children. Several studies have found that students who are given good parental supervision may not start sexual activity earlier than students who are under parental supervision (28).

The research also found that access to information directly influences reproductive health behavior. Sources of information obtained determine adolescent reproductive health behaviors. The internet and social media, which are available to adolescents, have given so much information that cannot be verified whether they are true and appropriate for adolescents. This in addition to access to pornography has been shown to affect the majority of adolescent sexual behavior. Based on the results of mass media research is a source of reproductive health information that is more important than parents, because the mass media provides a better picture of the wants and needs of adolescents. Both print and electronic mass media display text or images that can cause imagination and stimulate someone to try to imitate the scene (29).

Based on the results of an interview with one of the BK counseling teachers at Muhammadiyah 1 Junior High School, Sleman, Yogyakarta, the health promotion process in terms of the media there only uses Madding Club, the lack of media such as print media, electronic media, billboard media used to do health promotion can make students in receiving health education through health promotion feel bored. The method used in junior high school uses lectures and is accompanied by using PPT (Powerpoint) accompanied by images that are in accordance with the material but there is no audiovisual such as video so that it causes less enthusiasm and seems boring. According to the BK Teachers at Muhammadiyah 1 Mlati Sleman Yogyakarta Junior High School, the provision of support for reproductive education in the form of classical class services for all students who have problems in the field of reproductive health or not, providing special support for reproductive health in class VII, namely during the school orientation period, class VIII is conducting counseling, class IX is not given and if students have problems.

The model of health promotion about adolescent reproductive health is well designed by improving the process of health promotion about reproductive health both for adolescents themselves, stakeholders, and parents. Health promotion intended for adolescents can be a source of information for adolescents. Health promotion intended for stakeholders can encourage stakeholders to support healthy adolescent reproductive health. Health promotion which is intended for parents can also increase parents' knowledge about reproductive health so that it increases their role in assisting their children. After obtaining a concept model based on these statistical tests, the model concept is then compiled with a conceptual framework that was built before. The conceptual framework compilation model can be seen in Figure 3.

Figure 3 is a scheme of health promotion program models about adolescent reproductive health behaviors. This model is not only oriented on program performance for a moment. 


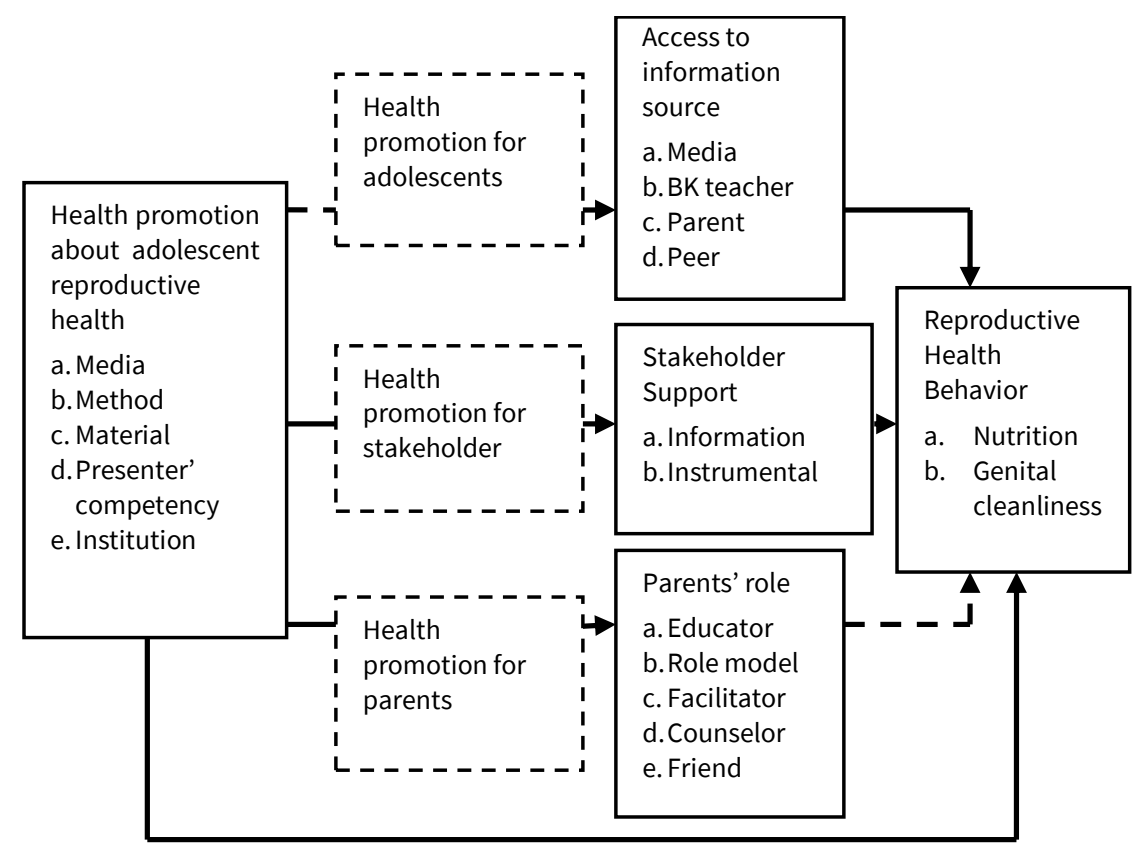

Figure 3. Health promotion models about healthy reproductive health behaviors

Sustainability of changes that can improve the quality of life is far more important.

\section{CONCLUSION}

Health promotion influences stakeholder support and parental roles. Health promotion does not affect access to information for adolescents, but directly influences reproductive health behavior. Reproductive health behavior is directly affected by health promotion, access to information, stakeholder support. The role of parents does not directly affect reproductive health behavior, but must be supported by health promotion to parents. Adolescents are expected to increase their activity in participating in counseling activities, increasing access to reproductive health information. Schools are expected to be able to increase their institutional role through a structured counseling schedule, provision of materials, provision of guidelines/modules for teenagers and parents. Parental knowledge is largely correlated with the presence of communication between parents and teens (30), and with research findings in Ethiopia, where $21.8 \%$ of teenagers are not interested in communicating with their parents because they consider them to have no reproductive health knowledge and communication skills (31).

\section{ACKNOWLEDGEMENT}

Thank you to Universitas Jenderal Achmad Yani Yogyakarta for providing support in this research.

\section{REFERENCES}

1. Kementerian Kesehatan Republik Indonesia, 2018. Survei Demografi dan Kesehatan Indonesia 2017. Available at: http://sdki.bkkbn.go.id/files/buku/2017IDHS.pdf
2. Adimora A A, Schoenbach VJ, Taylor EM, Khan MR, Schwartz RJ. Concurrent Partnerships, Nonmonogamous Partners, and Substance Use Among Women in the United States. American Journal of Public Health, 2011;101(1):12836. https://doi.org/10.2105/AJPH.2009.174292 PMid:20724694 PMCid:PMC3000736

3. Zone A, Bizu D, Aderaw Z, Kassa GM. Assessment of Early Sexual Initiation and Associated Factors among Preparatory School Students of FaggetaLekoma District. International Journal of Clinical Medicine, 2015;6:521-9. https://doi.org/10.4236/ijcm.2015.68070

4. Markos D, Kassa GM, Tsegay G, Abebe N, Bogale W, Tadesse $\mathrm{T}$, et al. Early Sexual Initiation and Associated Factors among. Science Journal of Clinical Medicine, 2015;4(5):805. https://doi.org/10.11648/j.sjcm.20150405.11

5. Kassa GM, Woldemariam EB. Prevalence of Premarital Sexual Practice and Associated. Global Journal of Medical Research: K Interdisciplinary, 2014;14(3):1-9.

6. Marston BM, Beguy D, Kabiru C. Predictors of Sexual Debut Among Young Adolescents in Nairobi's Informal Settlements. 22 International Perspectives on Sexual and Reproductive Health, 2013;39(1):22-32. https://doi.org/ $10.1363 / 3902213$

7. Kasim R, Draman N, Kadir AA, Muhamad R. Knowledge, Attitudes, and Practice of Preconception Care among Women Attending Maternal Health Clinic in Kelantan. Education in Medicine Journal, 2016;8(4):57-68. https://doi.org/10.5959/eimj.v8i4

8. Brechwald WA, Prinstein MJ. Beyond Homophily: A Decade of Advances in Understanding Peer Influence Processes. Journal of Research on Adolescence, 2011;21(1):166-79. https://doi.org/10.1111/j.1532-7795.2010.00721.x PMid:23730122 PMCid:PMC3666937

9. Mulu W, Yimer M, Abera B. Sexual Behaviours and Associated Factors Among Students at Bahir Dar University: A Cross-Sectional Study. Reproductive Health, 2014;11(84):1-12. Available at: http://www.reproductivehealth-journal.com/content/11/1/84 PMid:25481831 PMCid:PMC4271440 
10. Jonas K, Crutzen R, Borne BVD, Sewpaul R, Reddy P. Teenage Pregnancy Rates and Associations with Other Health Risk Behaviours: A Three- Wave Cross-Sectional Study Among South African school-going Adolescents. Reproductive Health, 2016:1-14. https://doi.org/10.1186/ s12978-016-0170-8 PMid:27142105 PMCid:PMC4855358

11. Hoffman-wanderer $Y$, Moult K, Müller A, Stefanie R. Social Science \& Medicine "You Have to Make a Judgment Call". E Morals, Judgments and the Provision of Quality Sexual and Reproductive Health Services for Adolescents in South Africa. Social Science \& Medicine Journal, 2016;148:71-78. https://doi.org/10.1016/j.socscimed.2015.11.048 PMid:26688551

12. Motuma A, Syre T, Egata G, Kenay A. Utilization of Youth Friendly Services and Associated Factors Among Youth in Harar Town, East Ethiopia: A Mixed-Method Study. BMC Health Services Research, 2016;16(272):1-10. https://doi.org/10.1186/s12913-016-1513-4 PMid:27423332 PMCid:PMC4947516

13. Evens E, Otieno-masala R, Eichleay M, Mccarraher D, et al. Of Biosocial Science: Post-Abortion Care Services for Youth and Adult Clients in Kenya: A Comparison of Services, Client Satisfaction and Provider Attitudes Youth and Adult Client Sinkenya. Journal of Biosocial Science, 2014;46(1):1-15. https://doi.org/10.1017/S0021932013000230 PMid:23745828

14. Mannava P, Durrant K, Fisher J, Chersich M, Luchters S. Attitudes and Behaviours of Maternal Health Care Providers in Interactions with Clients: A Systematic Review. Globalization and Health, 2015:1-17. https://doi.org/10.1186/s12992-015-0117-9 PMid:26276053 PMCid:PMC4537564

15. Jonas K, Crutzen R, Borne BVD, Reddy P. Healthcare Workers' Behaviors and Personal Determinants Associated with Providing Adequate Sexual and Reproductive Healthcare Services in Sub-Saharan Africa: A Systematic Review. BMC Pregnancy and Childbirth, 2017:1-19. https://doi.org/10.1186/s12884-017-1268-x PMid:28288565 PMCid:PMC5348841

16. Jonas K, Roman N, Reddy P, Krumeich A, Borne BVD, Crutzen R. International Journal of Nursing Studies Nurses' Perceptions of Adolescents Accessing and Utilizing Sexual and Reproductive Healthcare Services in Cape Town, South Africa: A Qualitative Study. International Journal of Nursing Studies, 2019;97:84-93. https://doi.org/10.1016/j.ijnurstu. 2019.05.008 PMid:31200221

17. Haberland N, Rogow D. Sexuality Education: Emerging Trends in Evidence and Practice. Journal of Adolescent Health, 2015;56(1):S15-S21. https://doi.org/10.1016/ j.jadohealth.2014.08.013 PMid:25528976

18. Violita F, Hadi EN. Determinants of Adolescent Reproductive Health Service Utilization by Senior High School Students in Makassar, Indonesia. BMC Public Health, 2019;19(286):1-7. https://doi.org/10.1186/s12889019-6587-6 PMid:30857523 PMCid:PMC6413438

19. Colarossi L, Silver EJ, Dean R. American Journal of Sexuality Education Adult Role Models: Feasibility, Acceptability, and Initial Outcomes for Sex Education. American Journal of Sexuality Education, 2014;9(February 2015):37-41. https://doi.org/10.1080/15546128.2014.903815 PMid:24883051 PMCid:PMC4038680
20. Envuladu EA, Kwaak AVD, Zwanikken P, Zoakah AI. Exploring the Factors Influencing Adolescent Sexual Behavior in Plateau State Nigeria. American Journal of Medicine and Medical Sciences, 2017;7(1):1-6. https://doi.org/10.5923/j.ajmms.20170701.01

21. Feleke SA, Koye DN, Demssie AF, Mengesha ZB. Reproductive Health Service Utilization and Associated Factors Among Adolescents (15 - 19 Years Old) in Gondar Town, Northwest. BMC Health Services Research, 2013;13(294):1-10. Available at:http://www.biomedcentral. com/1472-6963/13/294PMid:23915299 PMCid:PMC3750465

22. Kassahun EA, Gelagay AA, Muche AA, Dessie AA. Factors Associated with Early Sexual Initiation Among Preparatory and High School Youths in Woldia Town, Northeast Ethiopia: A Cross-Sectional Study. BMC Public Health, 2019;19(378):1-8. https://doi.org/10.1186/s12889-0196682-8 PMid:30947690 PMCid:PMC6450012

23. Morris JL, Rushwan H. International Journal of Gynecology and Obstetrics Adolescent sexual and reproductive health: The global challenges. International Journal of Gynecology and Obstetrics, 2015;131:S40-S42. https://doi.org/10.1016/ j.ijgo.2015.02.006 PMid:26433504

24. Ankomah A, Mamman-Daura F, Omoregie G, Anyanti J. Reasons for Delaying or Engaging in Early Sexual Initiation Among Adolescents in Nigeria. Adolescent Health, Medicine and Therapeutics, 2011;2:75-84. https://doi.org/ 10.2147/AHMT.S23649 PMid:24600276 PMCid:PMC3926781

25. Olugbenga-Bello Al, Adebimpe WO, Akande RO, Oke OS. Health Risk Behaviors and Sexual Initiation Among InSchool Adolescents in Rural Communities in Southwestern Nigeria. Int J Adolesc Med Health, 2014;26(4):503-10. https://doi.org/10.1515/ijamh-2013-0326 PMid:24643907

26. Ramiro L, Reis M, Matos MGD, Diniz JA. Artigo Original Educação Sexual, Conhecimentos, Crenças, Attitudes E Comportamentos Nos Adolescentes E Celeste Simões. Rev Port Saúde Pública, 2011;29(1):11-21. https://doi.org/ 10.1016/S0870-9025(11)70003-7

27. Nnadi I. Early Marriage: A Gender-Based Violence and A Violation of Women's Human Rights in Nigeria. Journal of Politics and Law, 2014;7(3):35-40. https://doi.org/ 10.5539/jpl.v7n3p35

28. Ayalew A, Abreha K, Shumey A, Berhane K. Magnitude and Predictors of Early Sexual Debut Among High and Preparatory School Students in Northern Ethiopia: A School-Based Cross-Sectional Study Health Education Research \& Development. Journal of Health Education Research \& Development, 2015;3(3):1-8. https://doi.org/ 10.4172/2380-5439.1000151

29. Carrol JAK. Impact of Social Media on Adolescent Behavioral Health in California, 2011;(510):1-6. Available at: www.californiateenhealth.org

30. Crichton J, Ibisomi L, Obeng S. Mother-Daughter Communication About Sexual Maturation, Abstinence, and Unintended Pregnancy: Experiences from an Informal Settlement in Nairobi, Kenya. Journal of Adolescence, 2012;35(1):21-30. https://doi.org/10.1016/j.adolescence. 2011.06.008 PMid:21783241 
31. Shiferaw K, Getahun F, Asres G. Assessment of Adolescents' Communication on Sexual and Reproductive Health Matters with Parents and Associated Factors Among Secondary and Preparatory Schools' Students in Debremarkos Town, North West Ethiopia. Reproductive Health, 2014;11(2):1-10. Available at: http://www.reproduc tive-health-journal.com/content/11/1/2 PMid:24401028 PMCid:PMC3892069 